\title{
Influence of microclimate on the directional dependence of sandstone pillar weathering in Angkor Wat temple, Cambodia
}

\author{
Tetsuya Waragai ${ }^{1 *}$ (D) and Yusuke Hiki ${ }^{2}$
}

\begin{abstract}
Angkor Wat temple, mainly composed of sandstone blocks, displays a type of religious architecture that signifies the worldviews of the Khmer and Hindu religions. The temple is a part of a UNESCO World Heritage site. However, there are numerous occurrences of hollows, i.e., depression-like notches, that have developed at the base of its sandstone pillars due to wet-dry and salt weathering. These pillars are variably weathered due to differences in the directions of the pillar surfaces and galleries in the temple. In this study, we analyze the differences in the hollow depths based on the sandstone hardness and water content, as well as a 5-year record of the temperature and humidity in the galleries. The results show that the hollow depths are profound in the outsides of the inner pillars and shallow on the northern side of the first gallery. The hollow depth increases with increasing values obtained by multiplying water content and moisture fluctuations, resulting from direct insolation together with rainfall.
\end{abstract}

Keywords: Sandstone, Microclimate, Angkor Wat temple, Cultural heritage, Moisture condition

\section{Introduction}

\section{Cultural stone weathering research}

The Angkor complex which is composed of temples such as Angkor Wat, Angkor Thom, Ta Keo and Ta Prohm, and West Barai is a religious structure and a hydrological system constructed from the 9th to 13th centuries of the Khmer period. Therefore, for more than 800 years, it has experienced significant natural and human-driven deteriorations.

In terms of natural deterioration, sandstone and laterite building materials rapidly deteriorate under tropical climates. Although chemical weathering is a major process in the tropics, as well as biochemical weathering (e.g., Liu et al. 2018), other forms of mechanical rock weathering such as wet-dry weathering (e.g., Waragai 2002, 2005a; Siedel et al. 2010; André et al. 2011), salt weathering (e.g., Uchida et al. 1999; Hosono et al. 2006; André et al. 2008; Siedel et al. 2008, 2010), and root wedging processes (Archaeological survey of India 2006) are also significant. For instance, Waragai (2002, 2005a)

\footnotetext{
* Correspondence: waragai.tetsuya@nihon-u.ac.jp

${ }^{1}$ Department of Geography, College of Humanities and Sciences, Nihon University, 3-25-40 Sakurajosui, Setagaya-ku, Tokyo 156-8550, Japan Full list of author information is available at the end of the article
}

suggested that, at the Angkor Wat temple, deterioration occurs because the sandstone blocks contain clay minerals, which are constantly exposed to severe cycles of wet-dry weathering. On the other hand, Uchida et al. (1999) reported salt efflorescence of minerals such as gypsum, calcite, and phosphate on the sandstone pillars of the Angkor Wat temple.

These weathering processes are thought to be restricted by direction dependent (Waragai 2005b; Waragai et al. 2006; André et al. 2012; Hiki 2012; Hiki and Waragai 2014; Waragai 2016), especially for the temples at Angkor. Regarding cultural stone weathering, previous studies have shown the importance of direction or aspect related to heating-cooling repetitions and moisture changes (Meierding 1993; Paradise 1995, 2002; Williams and Robinson 2000; Waragai 2017). Recently, a relationship between the weathering of sandstone pillars and the pillar water content in conjunction with the microclimatic conditions has been pointed out (Hiki and Waragai 2014). However, in their study, the microclimatic conditions of the air temperature and humidity were only measured for 1 year or less. Therefore, to obtain a representative view of the microclimatic conditions, longitudinal monitoring of the weathering environment 
must be performed. It is also necessary to understand the distribution and volume of the weathering within the temple. Accordingly, we discuss both the long-term monitoring of the weathering environment and the directional dependence of the weathering process based on the depths of the hollows (i.e., notches) in the sandstone pillars, which is regarded as a measure of the weathering volume.

\section{Study site}

The Angkor Wat temple, located in the tropics $(\mathrm{N}$ 13.412, E 103.867), was built with a masonry style of construction using blocks of sandstone and laterite during the reign of the Khmer King Suryavarman II (1113$1150 \mathrm{CE}$ ). The temple is surrounded by a moat that is $1300 \mathrm{~m}$ from north to south and $1500 \mathrm{~m}$ from east to west, with a central sanctuary made from sandstone blocks $62 \mathrm{~m}$ in height (Fig. 1). Three rectangular galleries of varying heights were constructed around the central sanctuary (Fig. 2a). These are called the first gallery, the second gallery, and the third gallery from the outer to central parts of the temple, respectively. The first and third galleries, which were selected as the study area, are colonnades composed of square sandstone pillars (Fig. 3a, b).

The first gallery is $200 \mathrm{~m}$ from north to south and $220 \mathrm{~m}$ from east to west and is the longest passageway with gopuras (Fig. 2a). The gallery has a height of $6 \mathrm{~m}$ with a vault that is $4 \mathrm{~m}$ above the ground (Fig. 2b). A closed wall supports the roof of the vault, and it is decorated with bas-reliefs as well as inner and outer pillars joined by beams (Fig. 3c, d). Several outer pillars are reinforced by mortar and/or iron hoops due to the development of vertical cracks and severe deterioration. Hollows are visible at the bases of the inner pillars (Fig. $3 \mathrm{c}, \mathrm{e})$. These hollows are continuing to grow via wet-dry weathering (e.g., Waragai 2005a; Hara and Waragai 2010; Siedel et al. 2010) and salt weathering (e.g., Uchida et al. 1999; Hosono et al. 2006; Siedel et al. 2008). The depths of the hollows are correlated to the directions faced by the pillars and the galleries.

The third gallery, located approximately $30 \mathrm{~m}$ above the ground, forms a square shape with a length of $70 \mathrm{~m}$ from north to south, and $70 \mathrm{~m}$ from east to west (Fig. 2a). The gallery surrounds the courtyards around the central tower of the sanctuary, and an enclosure wall with window is located along the outermost side of the sanctuary. The third gallery (Figs. 2c, 3b), which is characterized by a ventilated environment, differs from the first gallery, because the inside of third gallery is open on one side. A combination of 196 inner and outer pillars and the enclosure wall support the roof of the gallery. The pillars, which are reinforced and/or are developing cracks, are minuscule. However, hollows have developed at the bases of the inner pillars (Fig. 3f), producing sandstone fragments.

There is no evidence of hollow formation on the outer pillars at the first and third galleries. It is presumed that the differences in the shape of the pillar bases and the vertical loads are responsible for the formation of the hollows (Kambe et al. 2016).

According to Waragai and Hara (2011), the sandstone block has a specific gravity of 2.64, a dry unit weight of $2.30 \mathrm{~g} / \mathrm{cm}^{3}$, a saturated water content of $6 \%$, a porosity of $13 \%$, and a tensile strength (dry) of $9.4 \mathrm{MP}$.

Meteorological observation at the Angkor Wat temple (the observation point is shown in Fig. 1; AMOS) between 2011 and 2016 shows an annual average temperature of $27{ }^{\circ} \mathrm{C}$ with a total annual rainfall of $1633 \mathrm{~mm}$ (Waragai 2018). The monthly average temperature is the highest $\left(29.6{ }^{\circ} \mathrm{C}\right)$ in April and the lowest in January $\left(24.9^{\circ} \mathrm{C}\right)$, and the variation in the annual temperature is relatively small (Fig. 4). Conversely, the monthly rainfall from June to October is 243$358 \mathrm{~mm} / \mathrm{month}$ and that from December to February is $0.1-16 \mathrm{~mm} / \mathrm{month}$. Therefore, there is a clear distinction between the rainy and dry seasons at the study area.

\section{Methods/Experimental}

\section{Hollow depth measurements}

The temple galleries are precisely oriented in the cardinal directions (Fig. 2a), and hollows occur in the bases of all the inner pillars of the galleries. In the first gallery, there are 64 inner pillars in the northern $(1 \mathrm{~N})$ and southern (1S) galleries, and 38 inner pillars in the eastern $(1 \mathrm{E})$ and western $(1 \mathrm{~W})$ galleries. In the third gallery, there are a total of 32 inner pillars with hollows: 8 in each of the eastern (3E), western $(3 \mathrm{~W})$, northern $(3 \mathrm{~N})$, and southern (3S) galleries. Because the courtyards are in the enclosure wall of the third gallery, the pillar arrangement is opposite that of the first gallery (Fig. 2b, c). We define the inner pillars of the third gallery as pillars that have hollows at their bases.

To measure the hollow depth, we selected a total of 91 inner pillars from the first gallery and 16 inner pillars from the third gallery (Fig. 2a). Specifically, in the first gallery, we selected 28 pillars from the northern gallery $(1 \mathrm{~N}), 22$ pillars from the western gallery $(1 \mathrm{~W}), 19$ pillars from the eastern gallery (1E), and 22 pillars from the southern gallery (1S). The selected pillars are equivalent to approximately $45 \%$ of the total pillars in the first gallery. On the other hand, eight inner pillars were selected from each direction in the third gallery $(3 \mathrm{E}, 3 \mathrm{~W}, 3 \mathrm{~S}$, and $3 \mathrm{~N}$; 32 pillars in total).

Although hollows form on all sides of the inner pillars, we only measured the hollow depth at both the outside and inside hollows of the pillars using a caliper during August of 2012. The depth is defined as the maximum 


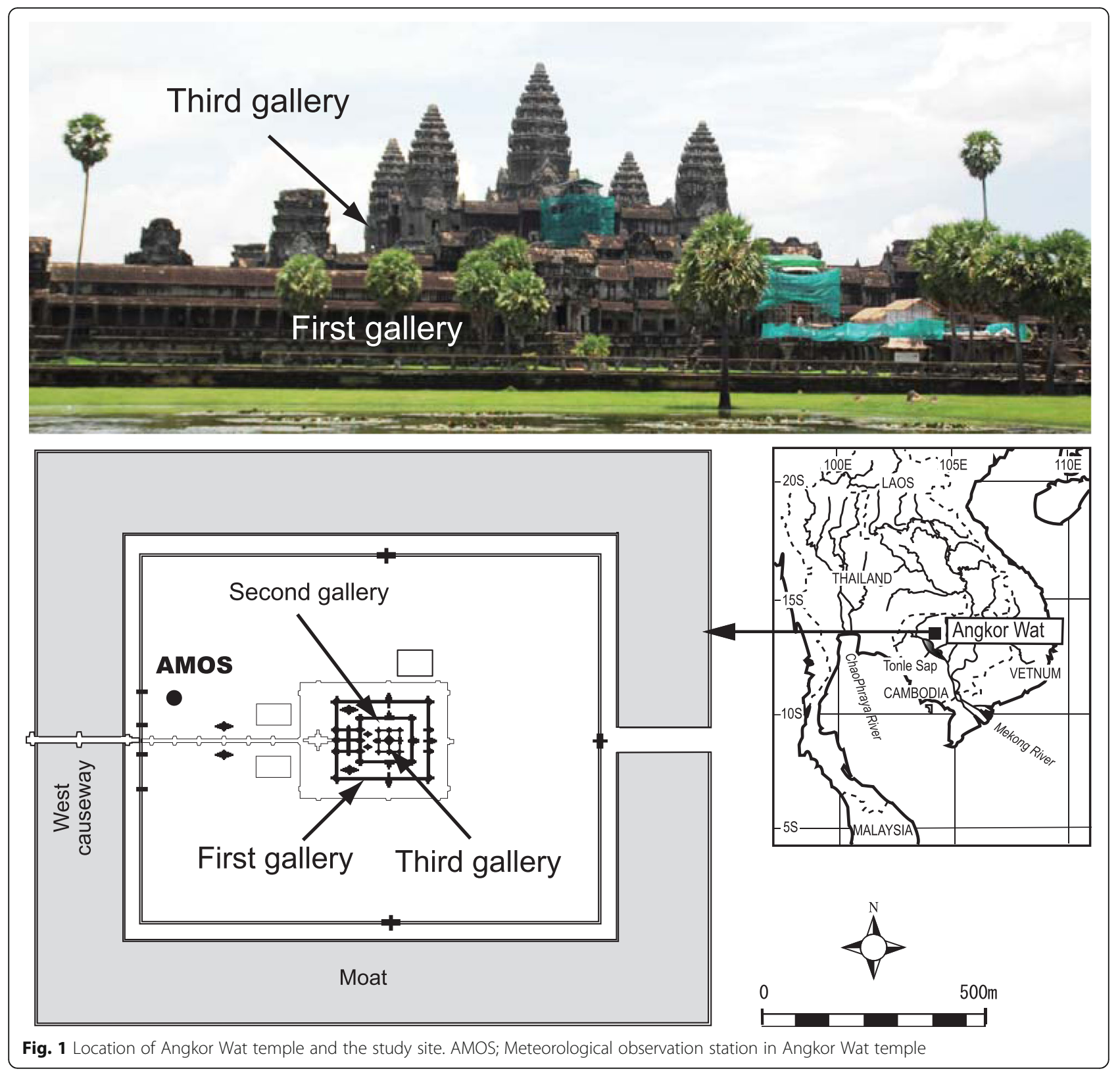

depth between the original surface and the innermost point of the hollow.

\section{Hardness measurements}

An Equotip 3 Hardness Tester (Proceq SA) was used to measure the hardness on the inside and outside of the pillars in August 2012. This device is often used in order to estimate in situ non-destructive hardness of stones (e.g., Aoki and Matsukura 2007; Wilhelm et al. 2016a, 2016b). Average hardness (the Leeb hardness; Kompatscher 2004) was calculated from five measurements on the innermost surfaces of the inside and outside hollows for all selected inner pillars in the first gallery. In the third gallery, the inside and outside hollows on two inner pillars in each direction were selected to measure the hardness.

\section{Water content measurements}

An infrared optical moisture meter (JT Engineering Inc., JE100) was used to measure the water content of the pillars. This meter measures the water content based on the amount of absorbance of reflected light converted from the amount of infrared light that bounces from an object (Matsukura and Takahashi 1999). For the gray sandstone at the Angkor Wat temple, water content is calculated based on the absorbance measured by the meter (Waragai et al. 2008). 


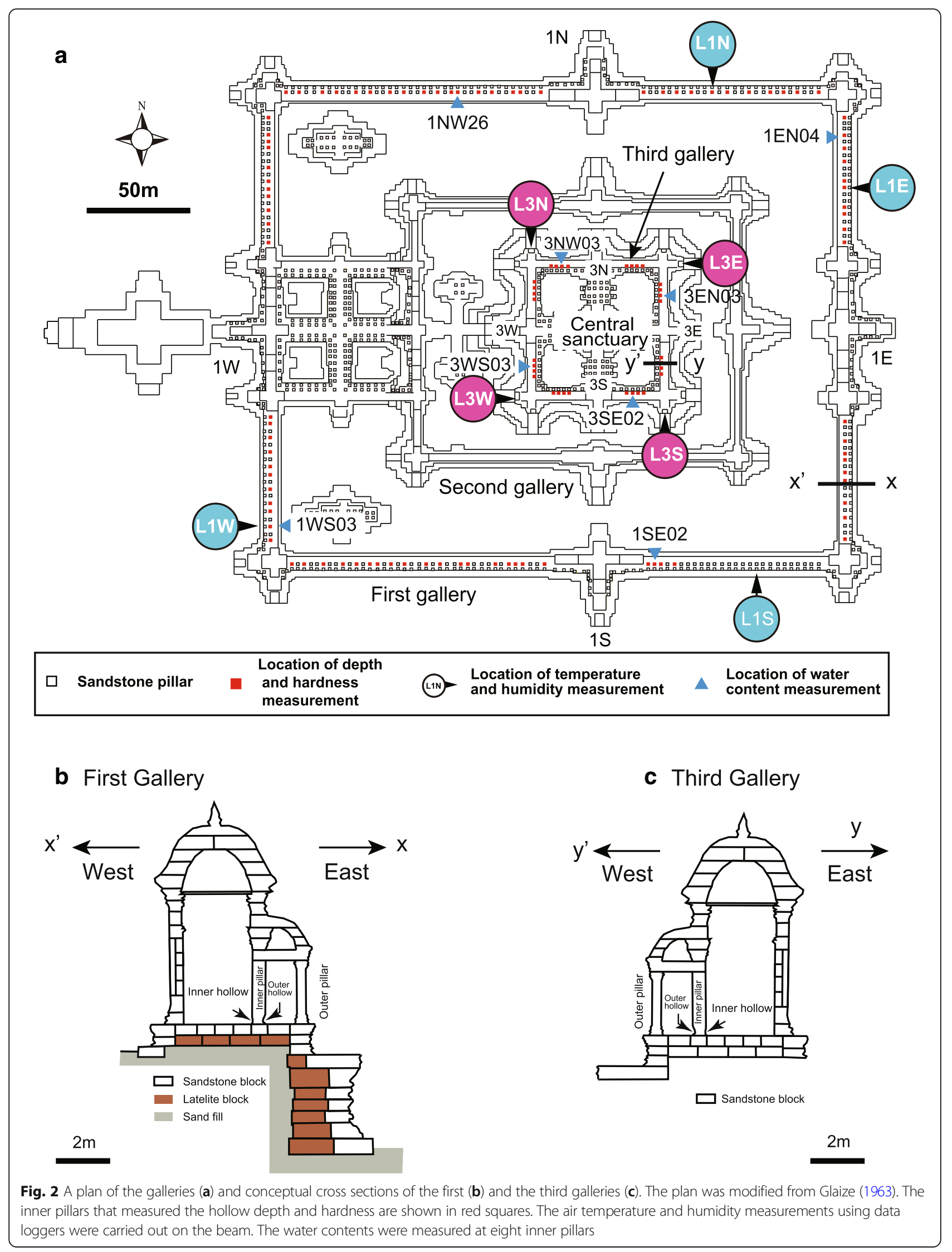



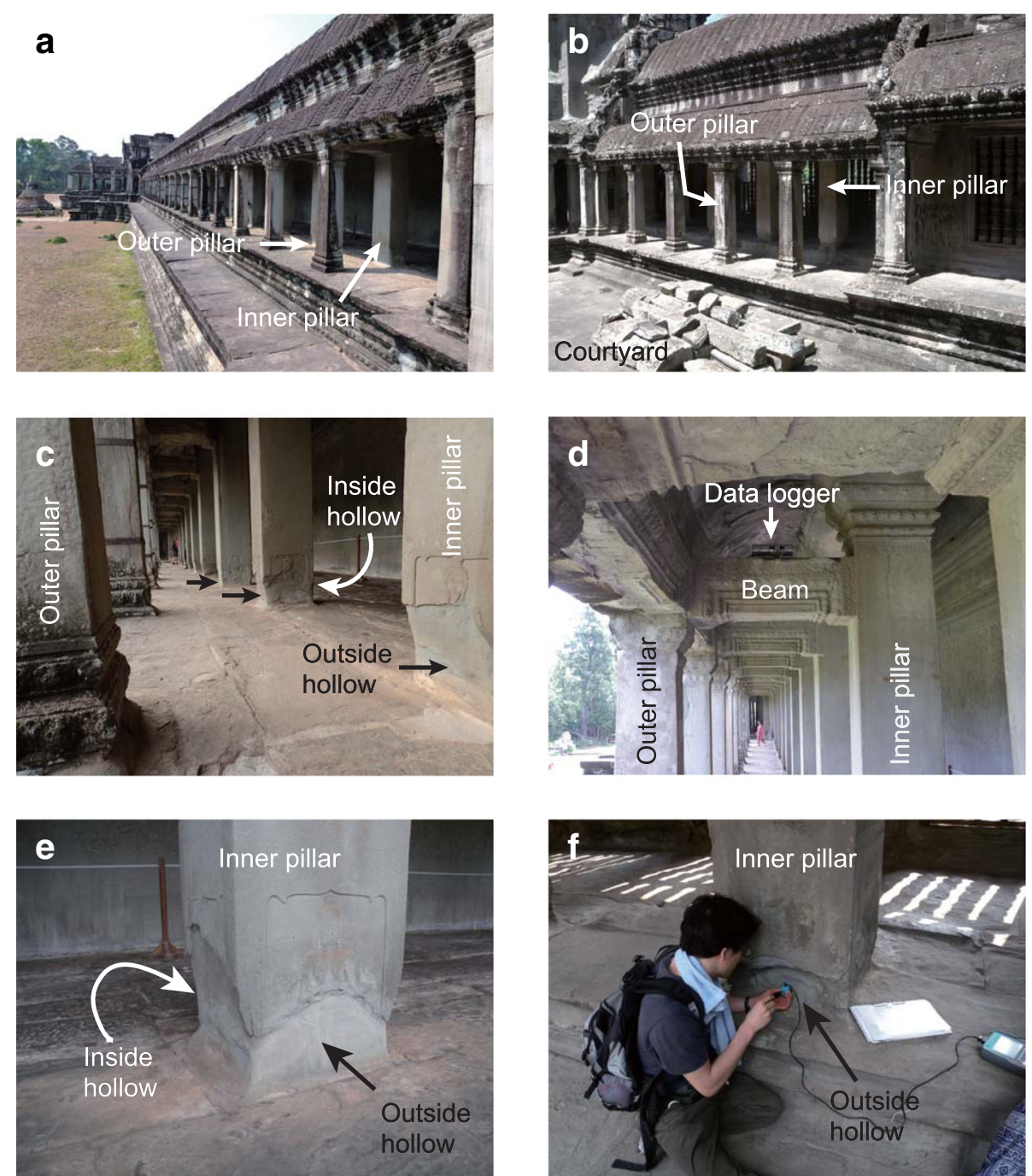

Fig. 3 Galleries and sandstone pillars of Angkor Wat temple. a Eastern side of the first gallery (1E). b Eastern side of the third gallery. c The inner and outer pillars in the first gallery. $\mathbf{d}$ A data logger on the beam in the first gallery. $\mathbf{e}$ The inner pillar accompanied with the hollow of the first gallery. $\mathbf{f}$ The hardness measurement on the inner pillar at the third gallery

To measure the water content, eight pillars (1NW26, 1EN04, 1SE02, 1WS03; 3NW03, 3EN03, 3SE02, 3WS03) were selected from each cardinal direction in the galleries for each hollow on the inside and outside of the pillars (Fig. 2a). The hollow surfaces of the selected pillars were measured nine times in the first gallery (around 10:00, 15:50, August 10, 5:50, 7:00, August 11, and 10:20, 11:30, 15:30, 16:20, 17:30, August 12, 2012), and five times on pillars of the third gallery (around 10:00, 11:30, 15:00, 15:50, 16:40, August 14, 2012).

\section{Weathering environment monitoring}

To analyze the effects of the weathering environment due to the different directions of the galleries, the air temperature and relative humidity were simultaneously measured from August 22, 2011 to September 6, 2015.
Measurements were obtained in 30- or 60-min intervals using eight data loggers (Onset Computer Co., H08-032-08 and T\&D Co., CTD-RTR-52A). Data logger installation points are shown in Fig. 2a. Four data loggers were installed on the beam connecting the inner and outer pillars of each cardinal direction in the first gallery (Fig. 3d). Another set of four data loggers was installed on the back of a lintel at each corner of the third gallery.

\section{Results}

Hollow depths of the inner pillars

The results of the hollow depth measurements in the first gallery are shown in Table 1 and Fig. 5. Table 1 shows that the depth ranges from 4.0 to $95.4 \mathrm{~mm}$ (with an average of $34.1 \mathrm{~mm}$ ) for the outside hollows, and 0 


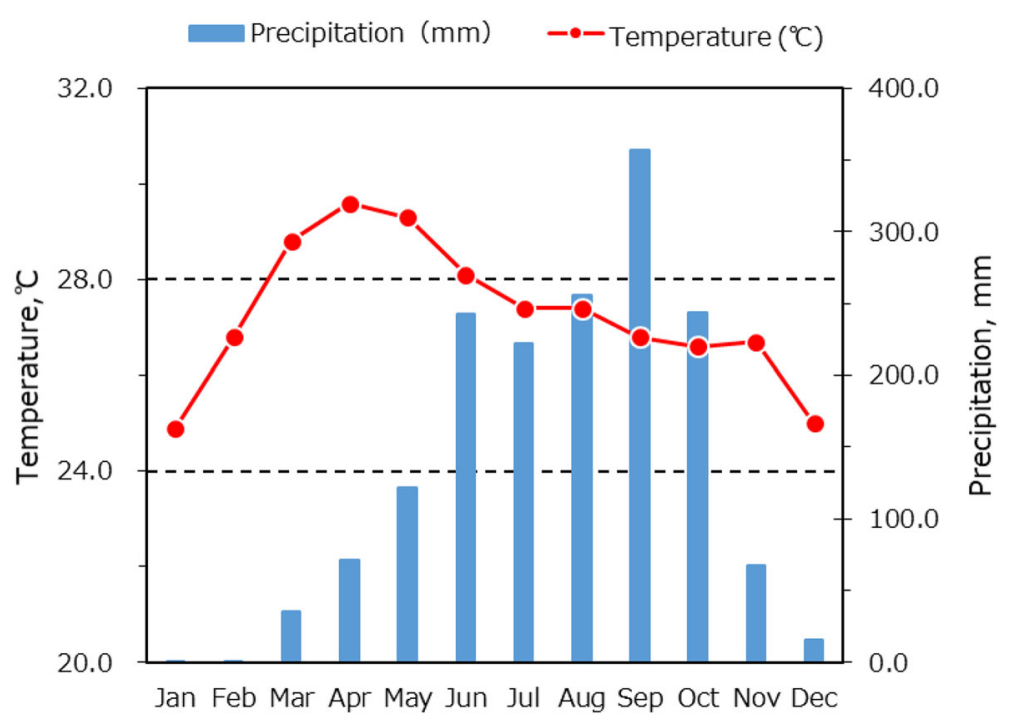

Fig. 4 Monthly average temperature and precipitation based on the meteorological observation between 2011 and 2016 at Angkor Wat temple (AMOS)

$36.0 \mathrm{~mm}$ (with an average of $12.9 \mathrm{~mm}$ ) for the inside hollows. The outside hollows were noticeably deeper than the inside hollows. Figure 5 shows the distribution of the hollow depth, grouped into classes at an interval of $10 \mathrm{~mm}$ depth. Many of the outside hollows exhibited more than $20 \mathrm{~mm}$ depth, except in the northern gallery. On the other hand, depths of less than $20 \mathrm{~mm}$ are dominant $(90 \%)$ in the inside hollows. Depths are elevated in the outside hollows, but shallow in the inside hollows. We then compared the depths of the outside hollows to the gallery directions finding that $1 \mathrm{E}$ (with an average of $46.5 \mathrm{~mm}$ ), followed by $1 \mathrm{~S}$ (with an average of $34.8 \mathrm{~mm}$ ), $1 \mathrm{~W}$ (with an average of $33.6 \mathrm{~mm}$ ), and $1 \mathrm{~N}$ (with an average of $21.4 \mathrm{~mm}$ ). In particular, the outside hollows with more than $50 \mathrm{~mm}$ depth occupy approximately $42 \%$ of the pillars in the eastern gallery (Fig. 5). Conversely, the outside hollows with less than $20 \mathrm{~mm}$ depth occupy approximately $57 \%$ of the pillars in the northern gallery. The depths of the inside hollows are as ranked as follows: $1 \mathrm{~W}$ (with an average of $16.6 \mathrm{~mm}$ ), $1 \mathrm{E}$ (with an average of $14.2 \mathrm{~mm}$ ), $1 \mathrm{~S}$ (with an average of $12.5 \mathrm{~mm}$ ), and $1 \mathrm{~N}$ (with an average of $8.4 \mathrm{~mm}$ ). Therefore, the hollow depths in $1 \mathrm{~N}$ were shallower than those in the galleries in other directions.

The results of the hollow depths in the third gallery are shown in Table 1. The depths range from 21.1 to $134.1 \mathrm{~mm}$ (with an average of $53.9 \mathrm{~mm}$ ) for the outside hollows and 12.7-84.8 $\mathrm{mm}$ (with an average of

Table 1 Hollow depths of the inner pillars of the first and third galleries. Italics mean maximum values of the hollow depths

\begin{tabular}{|c|c|c|c|c|c|c|c|c|c|}
\hline & \multirow[t]{2}{*}{ Gallery and direction } & \multicolumn{4}{|c|}{ First gallery } & \multicolumn{4}{|c|}{ Third gallery } \\
\hline & & $1 \mathrm{~N}$ & $1 \mathrm{E}$ & 15 & $1 \mathrm{~W}$ & $3 \mathrm{~N}$ & $3 \mathrm{E}$ & 35 & $3 \mathrm{~W}$ \\
\hline \multirow[t]{6}{*}{ Outside of the pillar } & Number of measurement & 28 & 19 & 22 & 22 & 8 & 8 & 8 & 8 \\
\hline & Maximum depth, mm & 48.5 & 95.4 & 84.0 & 61.6 & 74.8 & 103.9 & 52.8 & 134.1 \\
\hline & Minimum depth, mm & 4.0 & 9.0 & 4.2 & 7.0 & 27.8 & 35.5 & 21.1 & 35.3 \\
\hline & Average depth, mm & 21.4 & 46.5 & 34.8 & 33.6 & 49.5 & 64.7 & 37.4 & 64.0 \\
\hline & Standard deviation, mm & 13.8 & 19.7 & 18.6 & 15.5 & 13.6 & 19.4 & 12.6 & 34.2 \\
\hline & Average depth of all directions, $\mathrm{mm}$ & 34.1 & & & & 53.9 & & & \\
\hline \multirow[t]{6}{*}{ Inside of the pillar } & Number of measurement & 28 & 19 & 22 & 22 & 8 & 6 & 8 & 8 \\
\hline & Maximum depth, mm & 28.3 & 36.0 & 29.0 & 32.0 & 64.8 & 68.7 & 68.7 & 84.8 \\
\hline & Minimum depth, mm & 0.0 & 6.0 & 0.0 & 4.9 & 29.0 & 40.5 & 12.7 & 27.2 \\
\hline & Average depth, mm & 8.4 & 14.2 & 12.5 & 16.6 & 43.4 & 48.4 & 49.9 & 45.6 \\
\hline & Standard deviation, mm & 7.6 & 7.8 & 8.4 & 8.9 & 14.2 & 9.0 & 20.4 & 20.8 \\
\hline & Average depth of all directions, $\mathrm{mm}$ & 12.9 & & & & 46.8 & & & \\
\hline
\end{tabular}




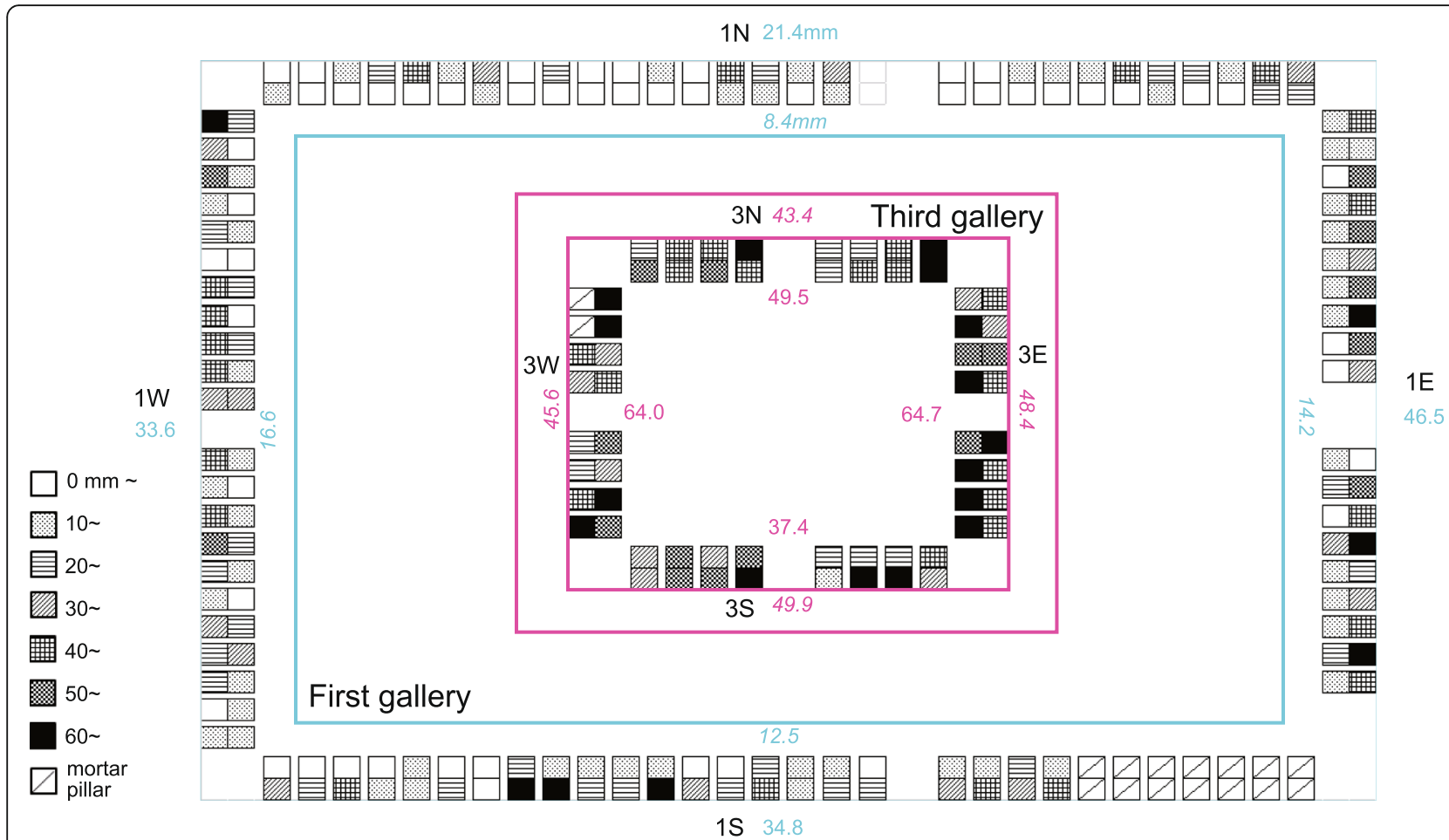

Fig. 5 Hollow depths of sandstone inner pillar at galleries of Angkor Wat temple. Numbers of upright and italic show the average depth of outer hollow and the average depth of inner hollow, respectively

$46.8 \mathrm{~mm}$ ) for the inside hollows. The average depth of the outside hollows is approximately $7 \mathrm{~mm}$ deeper than that of the inside hollows. A depth difference between the inside and outside hollows is observed for $3 \mathrm{E}$ and $3 \mathrm{~W}$ in the third gallery; however, this difference is smaller than that observed in the first gallery (Fig. 5). As shown in Fig. 5, when the depths of the outside hollows are compared with the directions of the third gallery, it indicates that $3 \mathrm{E}$ and $3 \mathrm{~W}$ are the largest (with an averages of 64.7 and $64.0 \mathrm{~mm}$, respectively), followed by $3 \mathrm{~N}$ (with an average of $49.5 \mathrm{~mm}$ ) and 3S (with an average of $37.4 \mathrm{~mm}$ ). The outside hollows are more than $60 \mathrm{~mm}$ deep for $63 \%$ of the hollows in $3 \mathrm{E}$ and for more than $50 \%$ of the hollows in $3 \mathrm{~W}$. On the other hand, the inside hollows have depths of $49.9 \mathrm{~mm}$ in $3 \mathrm{~S}, 48.4 \mathrm{~mm}$ in $3 \mathrm{E}$, $45.6 \mathrm{~mm}$ in $3 \mathrm{~W}$, and $43.4 \mathrm{~mm}$ in $3 \mathrm{~N}$. The depth range of the inside hollows is smaller than that of the outside hollows, with no influence of the gallery direction.

\section{Sandstone hardness of the inner pillars}

The average hardness and standard deviations are shown in Fig. 6. The average hardness in the first gallery was 402 HLD in the outside hollows and 334 HLD in the inside hollows (Fig. 6). The hardness of the outside hollows was noticeably greater than the inside hollows. The maximum average hardness of the outside hollows, in decreasing order, is $1 \mathrm{~N}$ (438 HLD), 1W (411), 1W (383), and $1 \mathrm{E}$ (376). The difference between the maximum and minimum hardness is $62 \mathrm{HLD}$. On the other hand, the range of hardness in the inside hollows is small, ranging from 349 HLD (1S) to 319 HLD (1W). Therefore, the hardness of the hollows was high in the outside hollows in $1 \mathrm{~N}$, and the difference due to the gallery direction was negligible for the inside hollows.

The average hardness in the third gallery was 311 HLD for the outside hollows, and 323 HLD for the inside hollows. The hardness difference is small between both sides as well as gallery directions. The ranges from minimum to maximum hardness are from 289 HLD $(3 \mathrm{~N})$ to 341 (3S) for the outside hollows, and from 307 (3W) to 333 (3S) for the inside hollows. Therefore, it indicates that the outside and inside hollows, as well as the gallery directions, have no influence on the hardness.

\section{Water content of the inner pillars}

The results of the water content measurement in the first gallery are shown in Fig. 7 accompanied with the maximum and minimum concentrations. The water contents in the first gallery were $2.0-4.5 \%$ (with an average of $3.0 \%$ ) for the outside hollows, and $4.0-6.6 \%$ (with an average of $5.0 \%$ ) for the inside hollows. Average water contents of the inside hollows were approximately $2 \%$ higher than those of the outside hollows. Comparing the water content for each direction in the gallery, the outside hollows of $1 \mathrm{~N}$ was the highest 

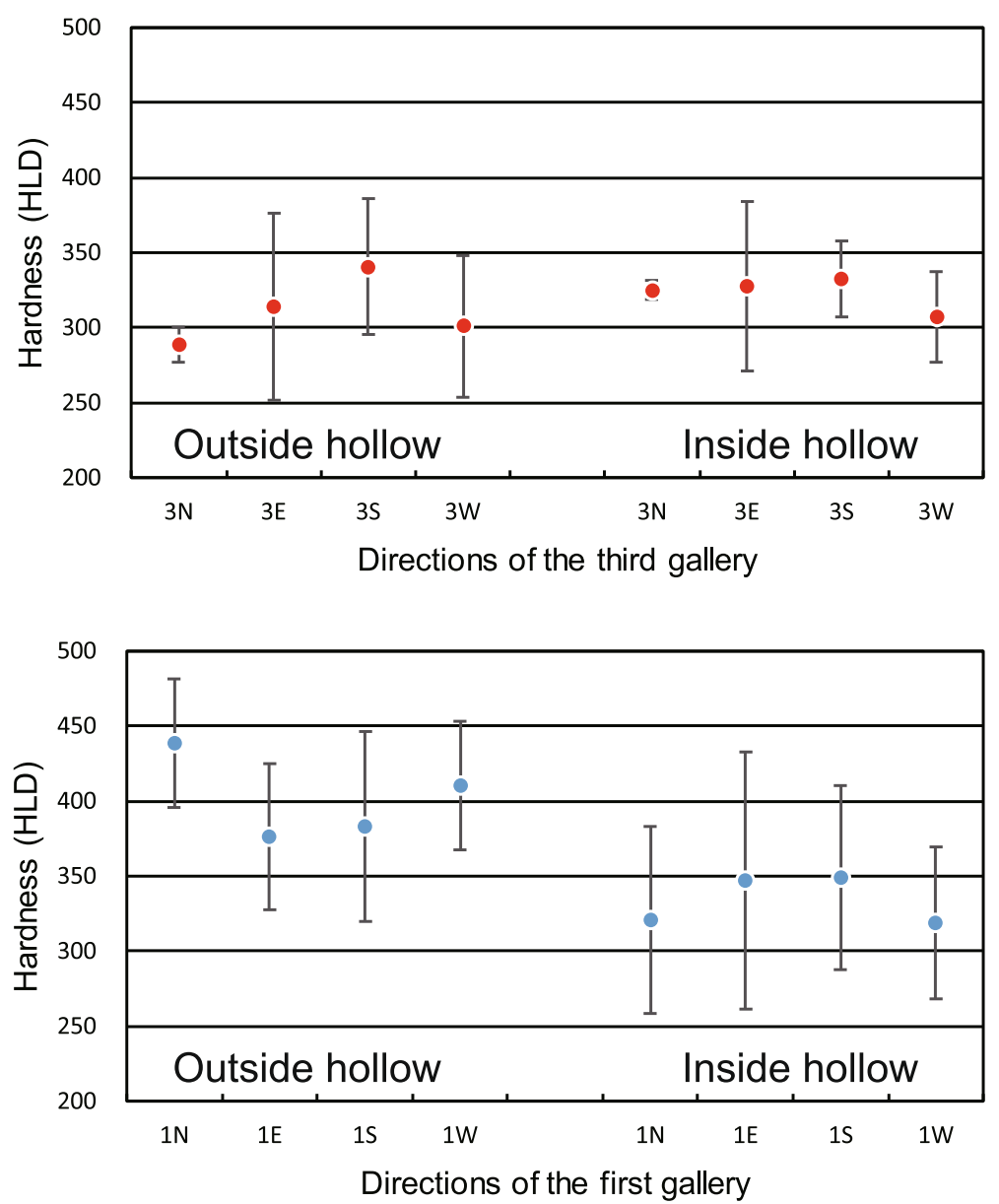

Fig. 6 Relationships between the hardness of the hollow and gallery directions. Bars indicate the standard deviation of hardness

contents (3.8\%) on average, followed by those of $1 \mathrm{~S}(3.2 \%)$, $1 \mathrm{E}(2.7 \%)$, and $1 \mathrm{~W}(2.4 \%)$. The water content of the inside hollows was the highest for $1 \mathrm{E}$ (5.2\%), while the lowest for 1S (4.7\%); however, the differences between the directions were small. The water contents were high for both the inside and outside hollows of $1 \mathrm{~N}$.

The results for the water content in the third gallery are shown in Fig. 7. The water contents ranged from 2.8 to $5.1 \%$ (with an average of $3.6 \%$ ) for the outside hollows and from 2.7 to $4.5 \%$ (with an average of $3.7 \%$ ) for the inside hollows, with only a small difference between the two. Comparing the water contents for each direction of the gallery, the outside hollows of $3 \mathrm{~N}$ was the highest $(4.5 \%)$ on average and those of 3S (3.1\%) was the lowest. The water contents of the inside hollows were also the highest for $3 \mathrm{~N}(4.4 \%)$ and the lowest for $3 \mathrm{~W}$ (3.1\%). The water contents tended to be high at the northern end of the third gallery despite the direction having relatively little influence.

\section{Weathering environments of the galleries}

To understand the microclimatic environment of the galleries, daily averages were calculated from the monitoring results of the temperature and relative humidity from 2011 to 2015 (Table 2). However, there are gaps in the data record due to data logger theft and humidity sensor malfunctions. In particular, humidity sensors installed in $3 \mathrm{~S}$ and $3 \mathrm{~W}$ (Fig. 2a) experienced a number of defects for a long period; therefore, they did not obtain enough data. The results of the relative humidity in $3 \mathrm{~S}$ and $3 \mathrm{~W}$ were therefore excluded from Table 2.

Regarding a comparison between the monitoring results and the directions of the galleries, it is found that the annual average temperatures were lowest in $1 \mathrm{~N}$ $\left(28.7{ }^{\circ} \mathrm{C}\right)$ and ranged from 29.6 to $29.7^{\circ} \mathrm{C}$ in the other directions of the first gallery. With respect to the humidity, $1 \mathrm{~N}$ had a maximum of $73 \%$ followed by $1 \mathrm{E}(70.8 \%)$, 1S (70.1\%), and $1 \mathrm{~W}(69.4 \%)$. The range in the humidity was small in $1 \mathrm{~N}(28 \%)$ and was larger in the other galleries (31-36\%). The average temperature in the third gallery ranged from $28.6(3 \mathrm{~N})$ to $29.1{ }^{\circ} \mathrm{C}(3 \mathrm{~S})$, a relatively small range. The average humidity was at a minimum of $70.0 \%$ in $3 \mathrm{E}$ and a maximum of $70.9 \%$ in $3 \mathrm{~N}$, also showing a small range. The difference between the maximum 

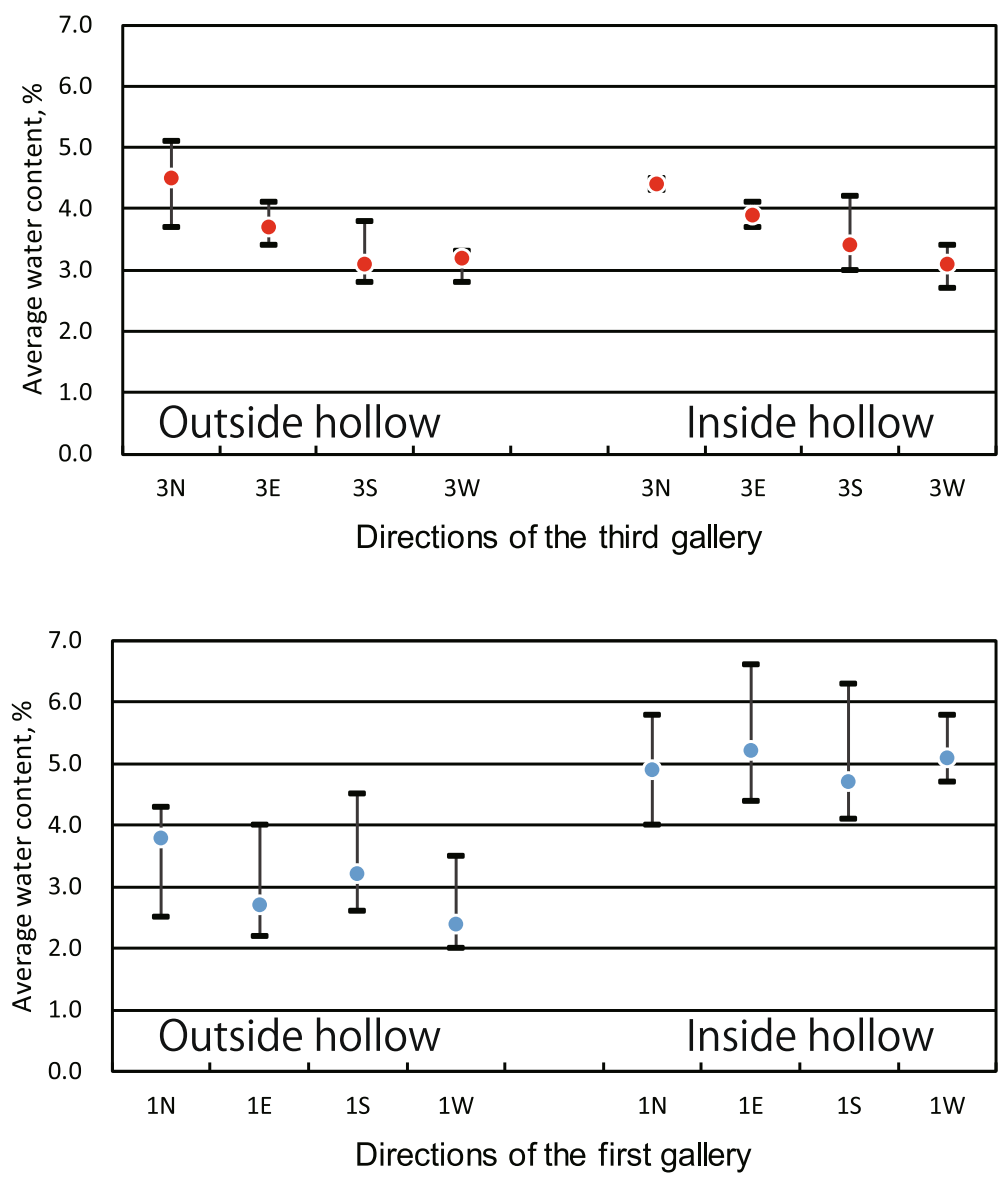

Fig. 7 Relationships between the water content of the hollow and gallery directions. Bars indicate ranges from maximum to minimum of water contents

Table 2 Statics of temperature and relative humidity of the first and third galleries between 2011 and 2015. Italics mean maximum values of the air temperature and relative humidity

\begin{tabular}{|c|c|c|c|c|c|c|c|c|c|}
\hline & \multirow[t]{2}{*}{ Gallery and direction } & \multicolumn{4}{|c|}{ First gallery } & \multicolumn{4}{|c|}{ Third gallery } \\
\hline & & $1 \mathrm{~N}$ & $1 \mathrm{E}$ & 15 & $1 \mathrm{~W}$ & $3 \mathrm{~N}$ & $3 \mathrm{E}$ & 35 & $3 W$ \\
\hline \multirow[t]{7}{*}{ Daily air temperature ${ }^{\circ} \mathrm{C}$} & Number of samples & 366 & 366 & 366 & 366 & 366 & 366 & 366 & 366 \\
\hline & Maximum & 33.3 & 34.3 & 33.3 & 34.2 & 32.5 & 32.2 & 32.1 & 31.7 \\
\hline & Minimum & 22.9 & 25.6 & 27.0 & 25.2 & 22.7 & 24.9 & 25.6 & 26.3 \\
\hline & Average & 28.7 & 29.7 & 29.6 & 29.6 & 28.6 & 28.7 & 29.1 & 28.8 \\
\hline & Standard deviation & 2.18 & 1.87 & 1.37 & 1.78 & 2.14 & 1.76 & 1.38 & 1.29 \\
\hline & Variance & 4.77 & 3.49 & 1.87 & 3.16 & 4.59 & 3.09 & 1.91 & 1.67 \\
\hline & Confidence interval (95.0\%) & 0.22 & 0.19 & 0.14 & 0.18 & 0.22 & 0.18 & 0.14 & 0.13 \\
\hline \multirow[t]{7}{*}{ Daily relative humidity, \% } & Number of samples & 366 & 366 & 366 & 366 & 365 & 366 & - & - \\
\hline & Maximum & 87.2 & 89.7 & 87.2 & 86.6 & 81.7 & 84.5 & - & - \\
\hline & Minimum & 58.9 & 53.6 & 56.0 & 53.6 & 54.6 & 56.6 & - & - \\
\hline & Average & 73.0 & 70.8 & 70.1 & 69.4 & 70.9 & 70.1 & - & - \\
\hline & Standard deviation & 6.71 & 7.98 & 8.52 & 8.64 & 6.11 & 7.26 & - & - \\
\hline & Variance & 45.07 & 63.76 & 72.62 & 74.60 & 37.39 & 52.68 & - & - \\
\hline & Confidence interval (95.0\%) & 0.69 & 0.82 & 0.88 & 0.89 & 0.63 & 0.75 & - & - \\
\hline
\end{tabular}


and minimum relative humidities was small in $3 \mathrm{E}$ (27.9\%) and $3 \mathrm{~N}(27.1 \%)$.

These results indicate that the northern gallery $(1 \mathrm{~N})$ has low temperatures and small changes in humidity throughout the year. In the third gallery, the northern gallery $(3 \mathrm{~N})$ had low temperatures, but the temperature difference between $3 \mathrm{~N}$ and the other galleries was small. The humidity differences due to the directions of the galleries were less than $1 \%$ in the third gallery.

\section{Discussion}

As mentioned above, the hollows develop at the bases of the inner pillars and the depths of the outside hollows are deeper than those of the inside hollows in the first gallery. The hollows in the third gallery are deep for the outside hollows, except in 3S. In addition, the hollow depths are shallow in the northern gallery, and show a difference due to the gallery direction. In previous studies, Takahashi and Matsukura (2006) point out global solar irradiance, as a major factor of directional dependence for depressions that developed on sandstone bridge piers. Paradise (2002) argues the importance of wet-dry changes in rocks from weathering rates of sandstone quarry surfaces in Petra, in addition to temperature changes due to insolation.

Several weathering processes are present for sandstone weathering at Angkor (e.g., Uchida et al. 1999; Waragai 2002, 2005a; Archaeological survey of India 2006; Hosono et al. 2006; André et al. 2008, 2011; Siedel et al. $2008,2010)$. However, there are very few discussions regarding the directional dependence of these processes (e.g., Waragai 2005b, 2016; Waragai et al. 2006; Hiki and Waragai 2014). This is due to the availability of climate data at the study area. Therefore, from the viewpoint of the microclimatic environment, we consider several reasons for the differences in the hollow depths due to the directions of the hollows and the galleries.

\section{Difference in the hollow depth due to pillar directions}

The average hollow depth in the first gallery was $34.1 \mathrm{~mm}$ deep for the outside hollows, and $12.9 \mathrm{~mm}$ deep for the inside hollows (Table 1). In the third gallery, the outside hollows were on average $53.9 \mathrm{~mm}$ deep and the inside hollows were on average $46.8 \mathrm{~mm}$ deep. Such depth differences between the inside and outside hollows results from changes in the water content related to the occurrence of wet-dry and salt weathering processes.

In the first gallery, since the inside of the inner pillars face a closed wall, the pillars are rarely exposed to direct insolation and ventilation (Fig. 2b). While the outsides of the inner pillars experience weather changes due to direct insolation and rainfall, since they face open air. Therefore, the microclimatic environment is considerably different between the inside and outside of the pillars. In particular, the environment brought a difference in the moisture conditions of the hollow surfaces. The water content during the rainy season was approximately $5 \%$ on average for the inside hollows and approximately $3 \%$ on average for the outside hollows (Fig. 7). Although these measurements were only performed during the rainy season, this indicates that the water content in the inside hollows is higher than that in the outside hollows throughout the year.

Pillar moisture changes due to rainfall are supposed from experimental results at the Angkor Wat temple (Hiki and Waragai 2014). They monitored water content at the base of the pillar by absorption after watering to the floor of the inner pillar (EN8) in the first gallery in August 2012. Based on the results, the water content of the inside and outside of the pillar increased by $2-3 \%$, approximately $30 \mathrm{~min}$ after the watering arrived. Although the water content of the outside returned to its initial value after 60 to $90 \mathrm{~min}$, the water content for the inside did not return to its initial value even after $400 \mathrm{~min}$. This indicates that changes in the water content become large on the outside whenever it rains, but small on the inside of the pillar.

The relationship between the water contents and the average hollow depth of the pillar in the gallery is shown in Fig. 8a. The depths in the first gallery tended to be deep for the outside hollows, which indicated low water content. Since the third gallery is a ventilated area, the water content is low in both the inside and outside hollows. The reason that the hollow depths in the third gallery are deeper than those in the first gallery is due to the large changes in the water content. The outsides of the inner pillars in the first and third galleries are easily deteriorated due to the larger changes in the water content based on changes in the weather.

According to the results, the hardness of the pillars in the first gallery showed an average of 402 HLD and 334 HLD in the outside and inside hollows, respectively, and a hard in the outside hollow (Fig. 6). The average hardness in the third gallery is smaller than that in the first gallery, and the difference between the outside hollows (311 HLD) and inside hollows (323 HLD) is small. As shown in Fig. 8b, although the hardness tended to decrease with increasing water content, a hardening of the surfaces in the hollows due to the efflorescence of gypsum (Uchida et al. 1999) might be predominant in the first gallery.

As for the reason why the hollow depths are deeper on the outsides, it is likely that the large and frequent moisture changes on the outsides of the pillars cause these surfaces to suffer wetting and desiccation via direct insolation.

\section{Differences in the hollow depth due to the gallery directions}

The moisture conditions of the pillars also differed with the gallery direction. In the first gallery, the average 
First gallery: Outside hollow, O Inside hollow

Third gallery: • Outside hollow, O Inside hollow
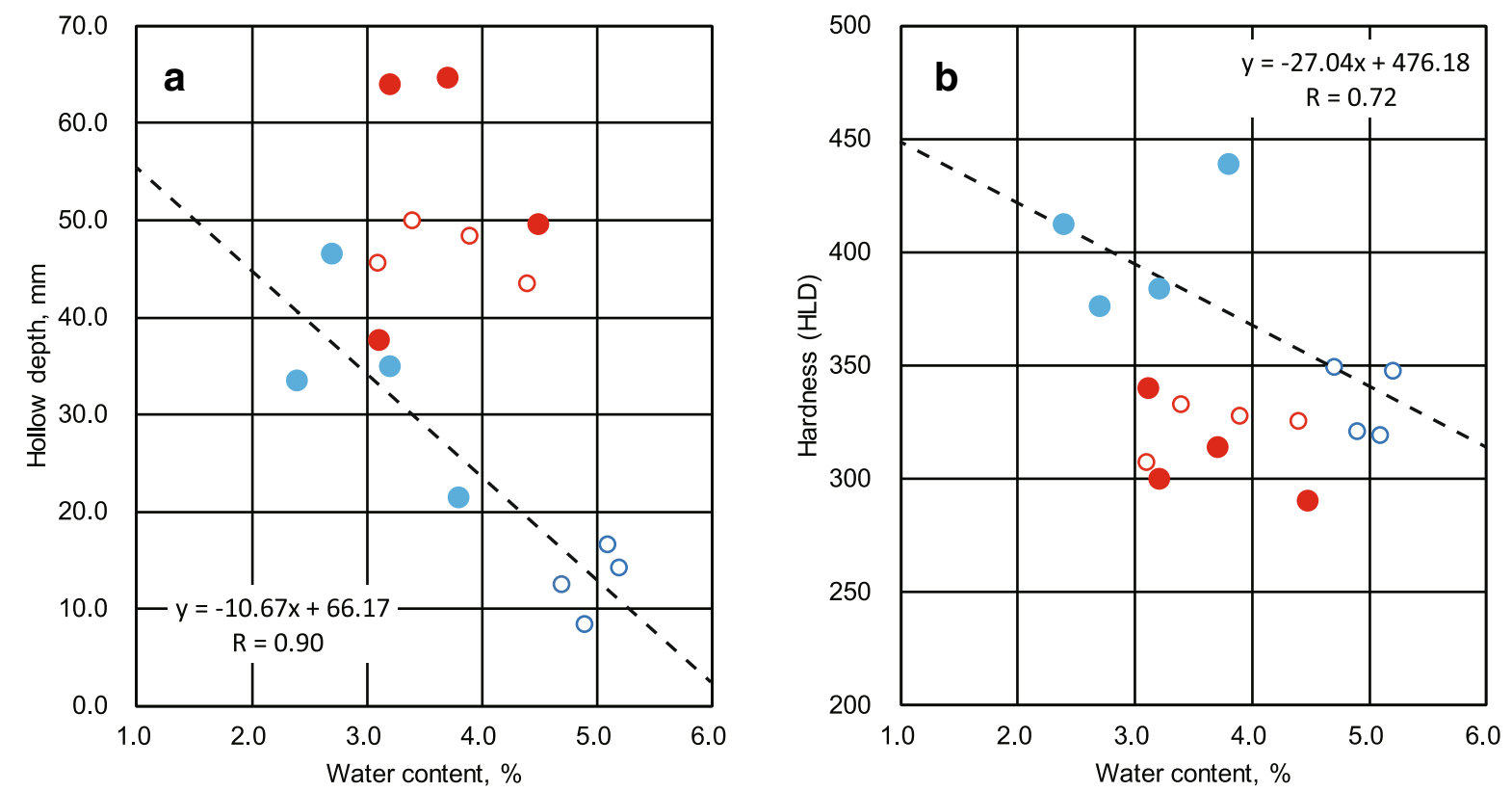

Fig. 8 Relationships between the hollow depth and water content (a), and the sandstone hardness and water content (b). Dashed lines accompanied with the equation and correlation coefficient $(R)$ indicate regression lines of the first gallery

hollow depth varied with the gallery direction, and was deeper in the eastern gallery (the outside hollow is $46.5 \mathrm{~mm}$ and the inside hollow is $14.2 \mathrm{~mm}$ ), followed by the southern ( 34.8 and $12.5 \mathrm{~mm}$ ), western (33.6 and $16.6 \mathrm{~mm}$ ), and northern $(21.4$ and $8.4 \mathrm{~mm}$ ) galleries (Fig. 5). Such differences in the hollow depths may be a consequence of the annual and daily wet-dry cycles.

Figure 9 shows the frequencies of the temperature and the relative humidity for each period: from June to October (the peak rainy season), and from December to February (the peak dry season). Seasonal temperature changes are small (Fig. 9a, b), whereas the humidity changes are large (Fig. 9c, d). For instance, the humidity is frequently between 60 and $70 \%$ in the dry season (Fig. 9c), whereas it switches to between 80 and $85 \%$ in the rainy season, varying by approximately $20 \%$ from season to season.

The humidity also has daily cycles and is a major factor in sandstone weathering (Paradise 2002). Therefore, an integrated daily range of relative humidity (IDRH), i.e., the difference between the daily maximum and minimum during the rainy and dry seasons, is used to compare with the average depths of the outside hollows (Fig. 10). It means that the IDRH is an index of the intensity of the wet-dry changes in a pillar. A high IDRH index indicates a large difference between the daily maximum and minimum humidities and therefore a high frequency of wet-dry changes in a pillar.
Figure 10 shows that the IDRH is approximately $5400 \%$ in the eastern gallery (1E; i.e., the gallery with the maximum hollow depth), while the northern gallery ( $1 \mathrm{~N}$; i.e., the minimum hollow depth) has an IDHR of approximately $4400 \%$. This indicates that the eastern gallery has a higher frequency of diurnal changes and therefore has more occurrences of wet-dry changes compared to the northern gallery. According to Waragai (2007), the surface temperature of the outside pillars reaches approximately $52{ }^{\circ} \mathrm{C}$ due to morning sunshine on the eastern side of the first gallery. The maximum surface temperature of the pillars in the western gallery, exposed to the afternoon sun, reaches $47{ }^{\circ} \mathrm{C}$ and is higher than that of the northern gallery (approximately $41{ }^{\circ} \mathrm{C}$ ). Insolation therefore dries the pillar and induces a large change in the pillar moisture.

There is also a relationship between the IDRH and the hollow depth in the third gallery. The hollow depths are the same in both the eastern (outside hollows $64.7 \mathrm{~mm}$, inside hollows $48.4 \mathrm{~mm})$ and western $(64.0$ and $45.6 \mathrm{~mm}$ ) galleries, whereas the northern (49.5/ $43.4 \mathrm{~mm})$ and southern $(37.4 / 49.9 \mathrm{~mm})$ galleries are shallow (Fig. 5). As shown in Fig. 10, the IDRH of 3N tended to be low compared to that of $3 \mathrm{E}$ in the third gallery. In addition, because the outside of the pillars in the third gallery face an open space (Fig. 2), the wet-dry change occurs more easily on the outside of the eastern, western, and northern galleries, and the insides of the 

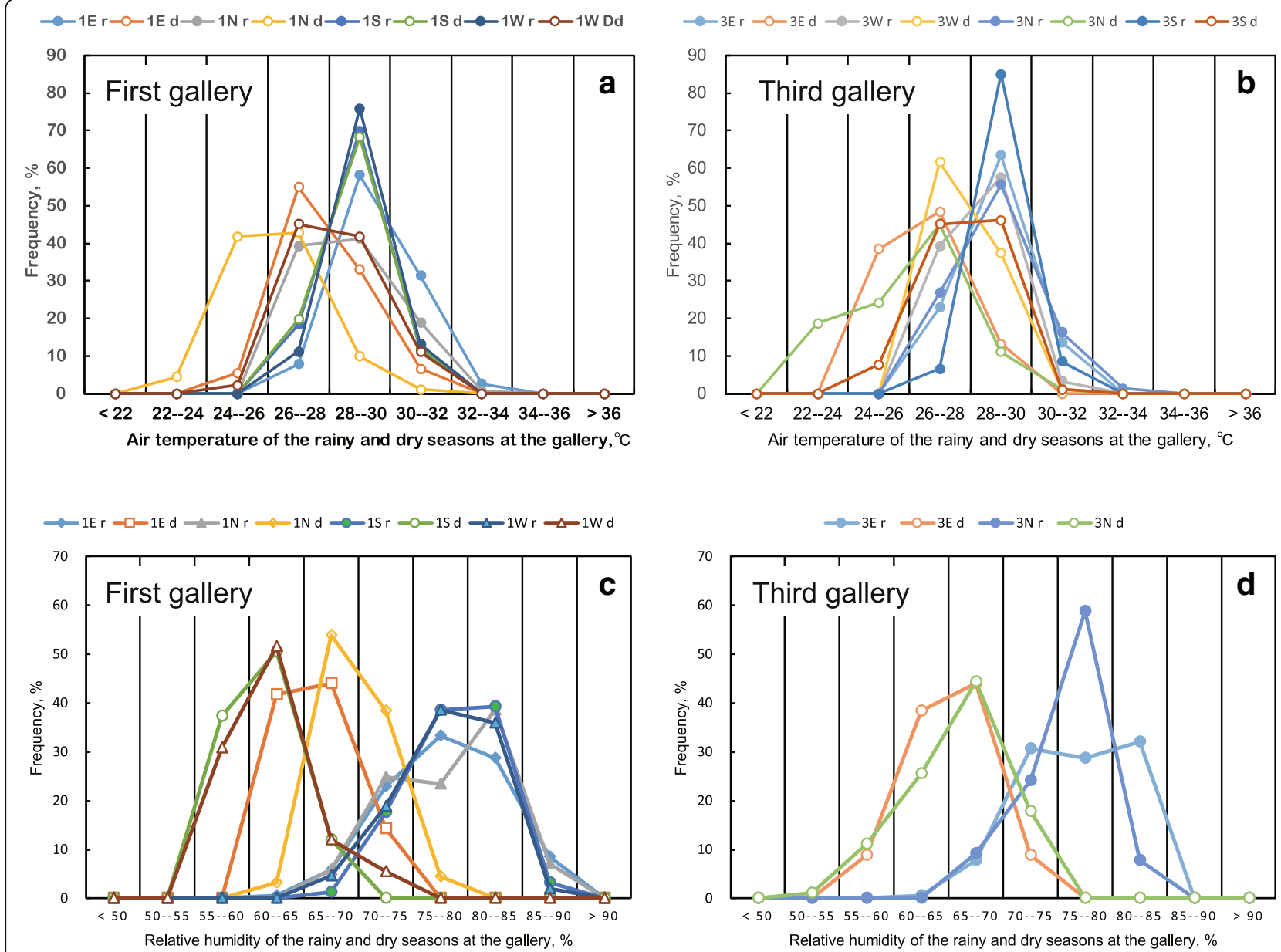

Fig. 9 Temperature and relative humidity frequencies of the galleries in the rainy and dry seasons. a Frequency of the temperature at the first gallery. $\mathbf{b}$ Frequency of the temperature at the third gallery. $\mathbf{c}$ Frequency of the relative humidity at the first gallery. $\mathbf{d}$ Frequency of the relative humidity at the third gallery. In the legend; $r$ rainy season (from June to October), $d$ dry season (from December to February)

pillars in the southern gallery, all of which are exposed to direct insolation. The rear parts of these galleries, which receive very little insolation, are not exposed to wet-dry repetitions.

The hollow depths in the third gallery were deeper than those in the first gallery, although the IDRH is lower (Fig. 10). This is possibly due to a previous period of vegetation cover. The first gallery may have been covered with dense tropical vegetation from the end of the Khmer Empire until the temple's rediscovery (1431$1860 \mathrm{CE}$ ). There has been a sustained, ventilated environment in the third gallery since the construction of the temple. Therefore, in the first gallery, which is located at a lower level, the weathering of the sandstone pillars may have been delayed during periods of high humidity. According to André et al. $(2008,2012)$, the weathering rate of the sandstone blocks at the Ta Keo temple (3.5 $\mathrm{km}$ from the Angkor Wat temple) increased due to the enhancement of sandstone desiccation via tree cutting in the 1920s. Cutting trees causing the root wedging, as a part of the conservation effort, induces ironically sandstone desiccation, increasing the impact of wet-dry weathering. Therefore, it is possible that the sandstone block deteriorates faster at present than it did in the past.

The hollow depths vary with gallery direction because the northern side of the first gallery maintains a high humidity condition with a small humidity range, which is contrary to the conditions in the other galleries. The intensity of the wet-dry changes in the northern gallery $(1 \mathrm{~N})$ is low compared to those of the other galleries; accordingly, there is very little sandstone pillar weathering in the northern gallery.

\section{Conclusions}

In this study, we examined the determinants of the hollow depth differences based on 5-year temperature and humidity observations, which sufficiently represent the environmental conditions in the galleries at the Angkor Wat temple. The results indicate that the outside 
First gallery: Outside hollow - Third gallery: Outside hollow

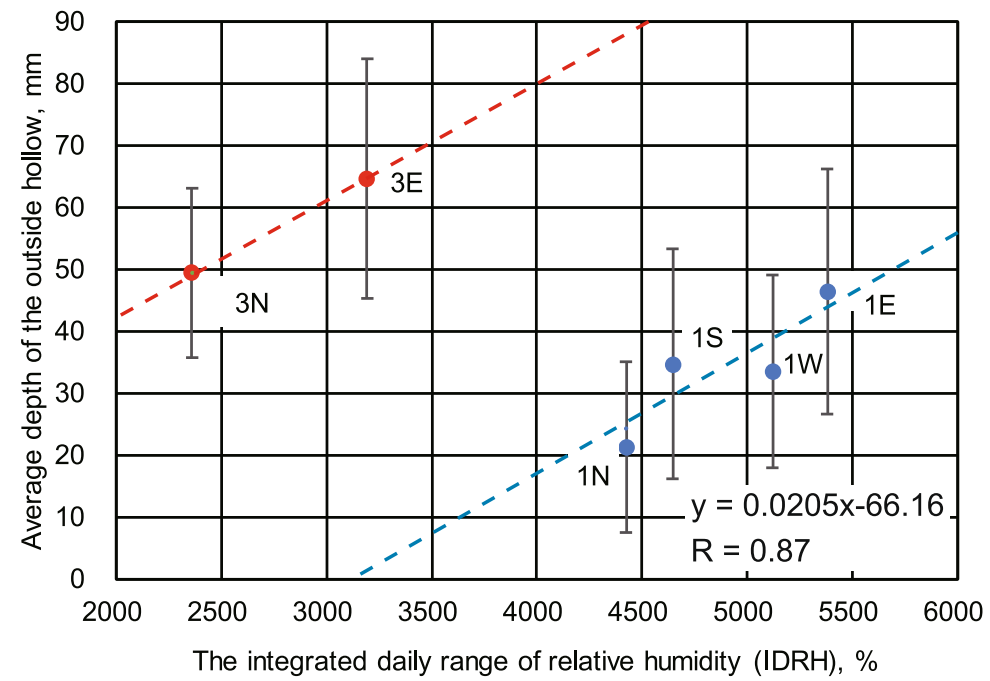

Fig. 10 Relationships between the average depth of the outside hollow and the integrated daily range of relative humidity (IDRH) of the galleries. A blue dashed line accompanied with an equation and correlation coefficient $(R)$ indicates a regression line of the first gallery. A red dashed line indicates a trend line of the third gallery. Bars indicate the standard deviation of the hollow depths

hollows of the inner pillars are deeper than the inside hollows in the first gallery. In the third gallery, the outside hollows are also deeper, except the $3 \mathrm{~S}$ hollow. This is due to the large and frequent moisture changes on the outsides of the pillars caused by frequent precipitation and desiccation via direct insolation.

The hollow depths are deep in the eastern gallery and shallow in the northern gallery and vary with the gallery direction. A possible reason for this directional dependence in the hollow depth can be attributed to the high frequency of humidity changes on the eastern side of the first gallery $(1 \mathrm{E})$. The intensity of the changes in the wet-dry cycle in the northern gallery $(1 \mathrm{~N})$ is low compared those in the other galleries, i.e., in the northern gallery, the sandstone pillar weathering is negligible. Further investigations, including monitoring of the water content and surface temperature of the sandstone pillars, should be performed to understand the directional dependence of the weathering processes in detail.

\section{Abbreviations}

1E: Eastern gallery in the first gallery; $1 \mathrm{~N}$ : Northern gallery in the first gallery; $1 \mathrm{~S}$ : Southern gallery in the first gallery; $1 \mathrm{~W}$ : Western gallery in the first gallery; $3 \mathrm{E}$ : Eastern gallery in the third gallery; $3 \mathrm{~N}$ : Northern gallery in the third gallery; 3S: Southern gallery in the third gallery; $3 \mathrm{~W}$ : Western gallery in the third gallery; IDRH: Integrated daily range of relative humidity

\section{Acknowledgements}

The authors wish to thank APSARA (the Authority for the Protection and Management of Angkor and the Region of Siem Reap) for the permission to conduct this research. The authors also thank Professor Y. Ishizawa (Sophia Univ.) and Mr. S. Miwa (Sophia Univ.) for their cooperation. We thank Dr. A. Hada (Ryukyu Univ.), Dr. T. Kajiyama (Nihon Univ.), and Mr. T. Maeda (Nihon Univ.) for their assistance in our field experiments.

\section{Funding}

This work was supported by JSPS KAKENHI Grant Number 22401005 and 26300008, in addition to the College of Humanities and Sciences of Nihon University.

\section{Availability of data and materials}

Please contact author for data requests.

\section{Authors' contributions}

TW proposed the topic, conceived, and designed the study. TW and YH carried out the field survey, analyzed the data, and shared their interpretation. YH collaborated with the corresponding author in the construction of manuscript. All authors read and approved the final manuscript.

\section{Competing interests}

The authors declare that they have no competing interests.

\section{Publisher's Note}

Springer Nature remains neutral with regard to jurisdictional claims in published maps and institutional affiliations.

\section{Author details}

'Department of Geography, College of Humanities and Sciences, Nihon University, 3-25-40 Sakurajosui, Setagaya-ku, Tokyo 156-8550, Japan. ${ }^{2}$ Suijyo High School, 2-1-45 Shiraume, Mito-shi, Ibaraki 310-0804, Japan.

Received: 25 April 2018 Accepted: 3 January 2019

Published online: 29 January 2019

\section{References}

André MF, Etienne S, Mercier D, Vautier F, Voldoire O (2008) Assessment of sandstone deterioration at Ta Keo temple (Angkor): first results and future prospects. Environ Geol 56:677-688

André MF, Phalip B, Voldoire O, Vautier F, Géraud Y, Benbakkar M, Constantin C Huber F, Morvan G (2011) Weathering of sandstone lotus petals at the Angkor site: a 1,000-year stone durability trial. Environ Earth Sci 63:1723-1739

André MF, Voldoire O, Roussel E, Vautier F, Phalip B, Peou H (2012) Contrasting weathering and climate regimes in forested and cleared sandstone temples of the Angkor region. Earth Surf Process Landf 37:519-532 
Aoki H, Matsukura Y (2007) A new technique for non-destructive field measurement of rock-surface strength: an application of the Equotip hardness tester to weathering studies. Earth Surf Process Landf 32:17591769. https://doi.org/10.1002/esp.1492

Archaeological survey of India (2006) Ta Prohm temple - a conservation stragtegy, Archaeological survey of India, New Delhi

Glaize M (1963) THE MONUMENTS OF THE ANGKOR GROUP"; A translation from the $4^{\text {th }}$ French edition by Tremmel, N. "A Guide of the Angkor Monuments" (1998), http://www.theangkorguide.com. Accessed 17 Jan 2019

Hara M, Waragai T (2010) Sandstone weathering forms and weathering depth of Angkor monuments, Cambodia. Ann Geogr 51:30-37 (in Japanese)

Hiki Y (2012) The study on weathering environment and weathering process of sandstone pillar composing the gallery of Angkor Wat temple. Master's thesis of Nihon University, Tokyo (in Japanese) (Title was translated by TW)

Hiki Y, Waragai T (2014) Relationships between the depth of hollow and moisture fluctuations of the sandstone pillar in the first gallery of Angkor Wat temple, Cambodia. Ann Geogr 56:25-37 (in Japanese)

Hosono T, Uchida E, Suda C, Ueno A, Nakagawa T (2006) Salt weathering of sandstone at the Angkor monuments, Cambodia: identification of the origins of salts using sulphur and strontium isotopes. J Archaeol Sci 33:1541-1551

Kambe N, Sato M, Takemura T, Waragai T, Ohno H, Inagaki H (2016) Weathering damage of sandstone columns in the first gallery of Angkor Wat: the approach from stress concentration and wet/dry cycle condition. Proc Jpn Soc Eng Geol 2016:197-198 (in Japanese)

Kompatscher M (2004) EQUOTIP - rebound hardness testing after D. Leeb. In: The International Measurement Confederation (ed) IMEKO TC5 Conference on Hardness Measurements, Theory and Applications in Laboratories and Industries, The International Measurement Confederation (IMEKO), Budapest, pp 66-72

Liu X, Meng H, Wang Y, Katayama Y, Gu JD (2018) Water is a critical factor in evaluating and assessing microbial colonization and destruction of Angkor sandstone monuments. Int Biodeterior Biodegrad 133:9-16. https://doi.org/ 10.1016/j.ibiod.2018.05.011

Matsukura Y, Takahashi K (1999) A new technique for rapid and non-destructive measurement of rock-surface moisture content; preliminary application to weathering studies of sandstone blocks. Eng Geol 55:113-120

Meierding TC (1993) Inscription legibility method for estimating rock weathering rates. Geomorphology 6:273-286

Paradise TR (1995) Sandstone weathering thresholds in Petra, Jordan. Phys Geogr $16: 205-222$

Paradise TR (2002) Sandstone weathering and aspect in Petra, Jordan. Z Geomorphol 46:1-17

Siedel H, Pfefferkorn S, Plehwe-Leisen E, Leisen H (2010) Sandstone weathering in tropical climate: results of low-destructive investigations at the temple of Angkor Wat, Cambodia. Eng Geol 115:182-192. https://doi.org/10.1016/j. enggeo.2009.07.003

Siedel H, Plehwe-Leisen E, Leisen H (2008) Salt load and deterioration of sandstone at the temple of Angkor Wat, Cambodia. In: Łukaszewicz JW Niemcewicz P (eds) 11th International Congress on Deterioration and Conservation of Stone, Proceedings vol. 1, Wydawnictwo Naukowe Uniwersytetu Mikołaja Kopernika, Torun, pp 267-274

Takahashi K, Matsukura Y (2006) Effects of insolation on depression growth of sand- stone blocks used for masonry bridge piers. Trans Jpn Geomorphol Union 27:259-281 (in Japanese with English abstract)

Uchida E, Ogawa Y, Maeda N, Nakagawa T (1999) Deterioration of stone materials in the Angkor monuments, Cambodia. Eng Geol 55:101-112

Waragai T (2002) Weatherability and weathering processes on building stones of Angkor Wat in Cambodia. In: Yüzer E, Ergin H, Tuğrul A (eds) Proceedings of International Symposium on Industrial Minerals and Building Stones, pp 353-361

Waragai T (2005a) Weathering environment and weathering processes on Angkor Wat building stones. Trans Jpn Geomorphol Union 26:239-257 (in Japanese with English abstract)

Waragai T (2005b) Spatial differences of weathering condition at galleries of Angkor Wat, Cambodia. Ann Geogr 46:28-38 (in Japanese)

Waragai T (2007) Rock temperature variations and their implications for sandstone column deterioration of Angkor Wat. Proc Inst Nat Sci Nihon Univ 42 (in Japanese with English abstract):15-26

Waragai T (2016) The effect of rock strength on weathering rates of sandstone used for Angkor temples in Cambodia. Eng Geol 207:24-35. https://doi.org/ 10.1016/j.enggeo.2016.04.006
Waragai T (2017) Weathering rates of stone-built heritages. J Geogr 126:455-471. https://doi.org/10.5026/jgeography.126.455 (in Japanese with English abstract)

Waragai T (2018) Installation and observation results of the Argos system at the Angkor Wat Meteorological Observation Station. Proc Inst Nat Sci Nihon Univ $53: 1-8$

Waragai T, Hara M (2011) The correlation between the water content and brightness of rock surfaces. Trans Jpn Geomorphol Union 32:317-326

Waragai T, Katagiri M, Miwa S (2006) A preliminary study on the direction dependence of sandstone column deterioration in the first gallery of Angkor Wat. Proc Inst Nat Sci Nihon Univ 41:39-50

Waragai T, Katagiri M, Miwa S, Yamauchi R, Ikeda M, Sasaki Y, Saruta T, Konno Y, Noji H (2008) Measurements of water content using an infrared optical moisture meter and tensile strength for sandstone of Angkor Wat. Ann Geogr 49:58-65 (in Japanese)

Wilhelm K, Viles H, Burke Ó (2016a) Low impact surface hardness testing (Equotip) on porous surfaces-advances in methodology with implications for rock weathering and stone deterioration research. Earth Surf Process Landf 41:1027-1038. https://doi.org/10.1002/esp.3882

Wilhelm K, Viles H, Burke Ó, Mayaud J (2016b) Surface hardness as a proxy for weathering behaviour of limestone heritage: a case study on dated headstones on the Isle of Portland, UK. Environ Earth Sci 75:931. https://doi. org/10.1007/s12665-016-5661-y

Williams RBG, Robinson DA (2000) Effects of aspect on weathering: anomalous behavior of sandstone gravestones in Southeast England. Earth Surf Process Landf 25:135-144

\section{Submit your manuscript to a SpringerOpen ${ }^{\circ}$ journal and benefit from:}

- Convenient online submission

- Rigorous peer review

- Open access: articles freely available online

High visibility within the field

- Retaining the copyright to your article

Submit your next manuscript at $\boldsymbol{\nabla}$ springeropen.com 